\title{
Choosing the Rate of Global Market Expansion by Entrepreneurial Firms
}

\author{
Jehiel Zif ${ }^{1}$ \\ ${ }^{1}$ Coller School of Management, Tel Aviv University, Israel \\ Correspondence: Jehiel Zif, Coller School of Management, Tel Aviv University, Israel.
}

Received: April 20, 2020

doi:10.5430/ijba.v11n4p13
Accepted: May 25, 2020

Online Published: June 10, 2020

URL: https://doi.org/10.5430/ijba.v11n4p13

\begin{abstract}
This paper outlines a rational for assessing the rate of global market expansion by entrepreneurial firms. Many entrepreneurial firms are dependent for their success on global market expansion. This is especially true about firms from relatively small countries. One can conceive of two major and opposing strategies for market expansion: market diversification and market concentration. The first strategy implies a fast penetration into a large number of markets in order to achieve fast growth and a first mover advantage. The second strategy is based on concentration of resources in a few markets and gradual expansion into new territories in order to test the response before committing too much effort. The paper is updating prior work on market expansion, taking into account entrepreneurial firms in the digital age. Firms with digital products don't have to depend on foreign distribution networks and they have new opportunities for fast entry into foreign markets. We propose a concise framework for determining the preferred rate of market expansion utilizing two key variables: the potential response function of customers and the complexity of the product. The paper include a discussion of ways to assess customers' response to entrepreneurial innovation and additional factors that can influence the market expansion decision.
\end{abstract}

Keywords: entrepreneurial, market expansion, market concentration, market diversification, response function, complex product, internationalization

\section{Introduction}

This paper explores how fast should entrepreneurial firms with an innovative product, or service, expand into global markets.

The literature has identified a number of factors which cause firms to internationalize rapidly:

Macro-level influences (Size of the firm home market, the emergence of a global niche market, technological developments in communication and production, global networks, digitization, competitive threat, cultural distance, information technology)

Micro-level influences (International experience, entrepreneurial and marketing orientation, vision, commitment, global connections, capabilities, resources, firm size, and high technology industry)

The entrepreneurial innovation (high value offering of product, or service, usually based on advanced technology)

In a review of the literature Cavusgil and Knight, (2015) summarized the factors listed above and emphasized the following:

1. Globalization and technological progress have made early internationalization possible for many start-up firms.

2. Early internationalizing firms tend to market innovative, unique, technologically advanced products.

3. Entrepreneurial leadership is behind the early internationalization effort.

4. A worldwide customers' base, an outcome of globalization, is a strong motivator

5. Firms from small domestic market are more likely to enter global markets faster.

Caviello (2006) demonstrated the importance of network dynamics. Coviello, Kano and Liesch, (2017), emphasized the critical dimensions of the digital content and the role of the individual decision maker. Oviatt and McDougall, (2005) reviewed the literature and proposed a model of forces influencing internationalization speed, including many of the factors listed above. Fernhaber, McDougal and Oviatt, (2007) stressed the importance of high growth industries, high knowledge intensity and global interconnectedness. Mass, Nicolau and Ruiz, (2006) studied the 
effects of diversification vs. concentration strategies on firm performance, they found that distribution, cultural distance and the non-repetitive character of product purchase moderated the relationship between foreign concentration-diversification and performance.

We propose three arguments relating to the research literature. First, the comprehensive models and frameworks, with their large number of variables, are theoretically and empirically sound and do a valuable job in explaining fast internationalization. However, these models are quite complicated and for the most part not designed for practical application. When a framework or a model has many variables it could serve as an explanation of strategic moves, but it is usually difficult to apply for decision making purposes. Second, a key variable which is missing from most of these models is the expected, or actual, response function (Concave, or S curve) (Ayal and Zif, 1979). This variable is probably omitted because it is difficult to measure in a statistical study of many firms. We argue that the potential response of customers to the innovative product and to the marketing efforts of the firm is a most crucial factor in determining the rate of market expansion. Third, the digital revolution with its many product variations had a major change on global marketing. Some SaaS products (software as a service) are very simple to market and purchase, but this is not the case for all digital products. The level of product complexity, in both digital and physical form, is a critical factor for market expansion plans. Although, "product" does appear in many studies as an important variable, the complexity issue, from a marketing point of view, is not usually addressed.

A global market expansion requires a number of strategic decisions:

1. How much effort the firm is capable and willing to commit in order to expand globally?

2. What should the order of market priority be for entry into global markets?

3. What should be the mode of entry, with resource allocation, into different foreign markets?

4. What should be the rate of market expansion into global markets?

This paper deals with the fourth decision. However, in practice the decision making process will be iterative, taking into account all four questions.

The paper has four parts:

1. Characteristics of entrepreneurial firms and response to uncertainty.

2. Alternatives of global market expansion.

3. A decision framework for the rate of market expansion by entrepreneurial firms.

4. Response function estimation.

5. Additional factors affecting the rate of market expansion.

6. Conclusion.

\section{Characteristics of Entrepreneurial Firms and Response to Uncertainty}

Most entrepreneurial firms are characterized by the following:

The firm is frequently started by managers with a technological background and limited knowledge of international business. At the early stages of the venture the number of experienced managers, particularly marketing managers is usually limited. Managers may not be familiar with frameworks to analyze and develop marketing plans and global expansion. The lack of experience can also lead to misinterpretation of signals in the early stages of marketing. For example: relying on trial data without repurchase data, and confusing sales to early adopters with more stable sales to the majority (Zif 2019).

The limited managerial and financial resources of most entrepreneurial firms, the number of strategic tasks and the newness of product, or service, innovation introduce a variety of uncertainty sources:

Product performance in use.

Product acceptance by customers.

Choosing the right customer segment.

Product and marketing acceptance by intermediaries

Nature and timing of competitive response.

Acceptable pricing level and policy

Administrative and bureaucratic roadblocks 
There are two kinds of risks associated with uncertainty: the risk of doing and the risk of not doing. These two kinds of risks are very relevant for many entrepreneurial firms that are considering market expansion. The first risk is the likelihood of loss as a result of expanding resources too fast on an unproven innovation, to find out that is does not work as expected, or that customers don't appreciate it sufficiently. The second risk is expanding too slowly with an innovative product or service and as result losing the momentum to competitors. This is particularly important in situation where the first winner takes all. Mckinsey and co. (2014) uploaded a YouTube video by the name: "Grow Fast or Die Slow" for software companies.

In this paper we propose a framework that can help decision makers in dealing with uncertainty regarding the desired rate of global market expansion.

\section{A Decision Framework for the Rate of Market Expansion by Entrepreneurial Firms}

The two typical strategies of market expansion are market concentration and market diversification (Ayal and Zif 1979, Mass, Nicolau and Ruiz 2006). See Figure 1.

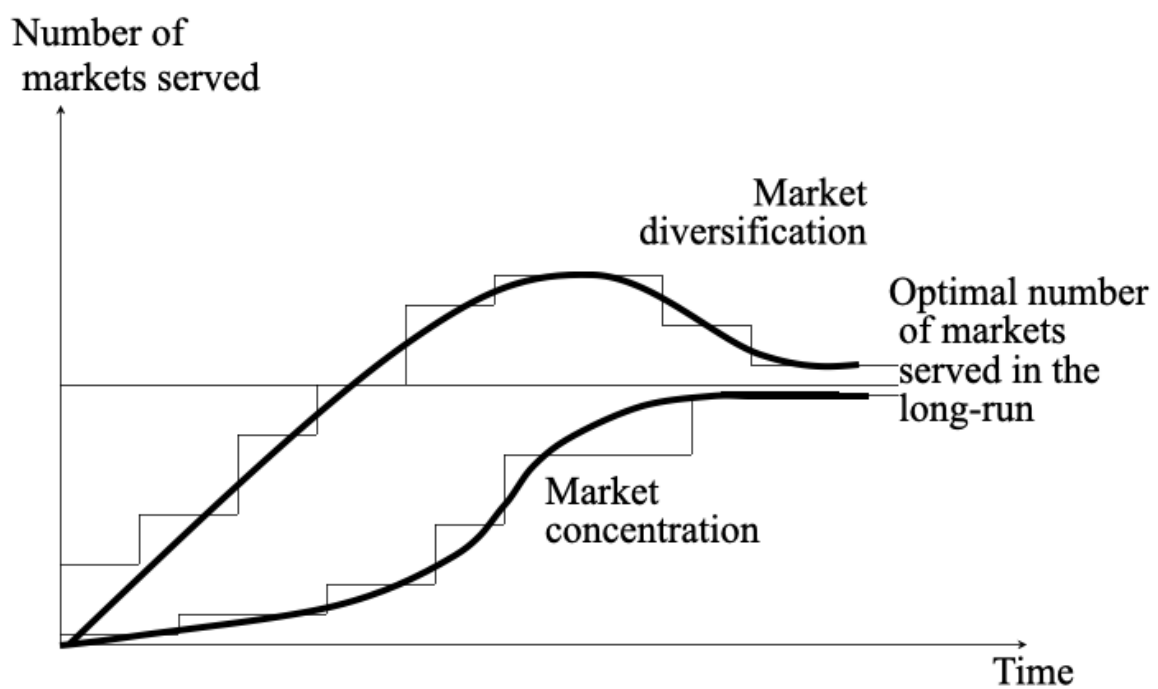

Figure 1. Alternative market expansion strategies

Market concentration is based on a gradual expansion from market to market. This is a conservative strategy that enables the firm to get sales feedback before committing higher resources to many markets. The entrepreneurial firm can use the early feedback to raise more capital, to recruit more staff and if justified to modify the product and the marketing plan for further expansion. With time and more resources, entry into each new market can be done with a more powerful concentration of effort.

Market diversification is a more aggressive strategy that is based on fast expansion into many markets. For an entrepreneurial firm with an innovative product the diversification expansion could have the advantage of a first mover. The strategy can contribute to fast growth if there is sufficient demand with no competition. As can be implied by Figure 1, fast entry can lead to withdrawal from some disappointing markets that do not justify the effort. The strategy is particularly appealing to firms with digital products without the complications of physical shipments. Entrepreneurial firms, many of which have limited resources, will need to allocate constrained resources to marketing efforts in each of the many markets and to possibly rely more heavily on intermediaries. In similarity with investment portfolios, serving many markets can have the advantage of overall sales stability.

Although, as can be seen in Figure 1, both strategies can lead, in the long run to the same number of markets served, the different patterns of growth are likely to lead to different outcomes in terms of competition, market share and profitability.

The choice between the two strategies of market expansion, or for a combination of elements as a mixed strategy, depends on some key factors. 
We propose that there are two key factors with the most influence on the choice.

The first key factor is the expected, or actual, response function. Sales response functions can be classified into two patterns: an S-curve function and a concave function (Kotler 1971). Graphic examples of these functions are presented in Figure 2.

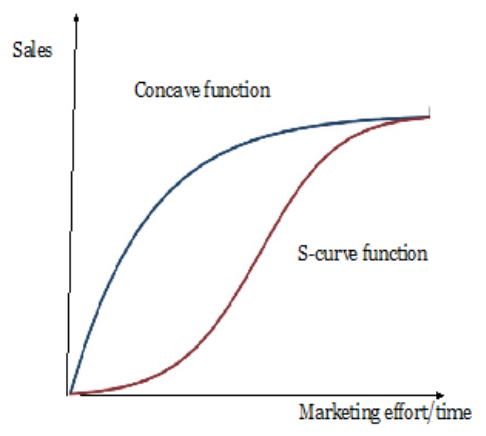

Figure 2. Concave and S-curve response functions

The S-curve is based on the assumption that the early efforts of introducing a new product do not generate a strong immediate sales response. There could be many reasons for a weak response including the time and effort needed to educate customers, the resistance to accept innovation by the distribution channels and aggressive response by competitors. These issues are common for many if not most innovations. With S-curve function it is likely to take a concentrated marketing effort until a take-off response in sales is reached. There are a number of reported cases of geographic market expansion which support the S-curve function (Hofer 1975). When this type of response is recognized by the firm, the expansion strategy is going to follow a concentrated pattern. There is no sense to quickly enter many markets without sufficient effort in each market to achieve a take-off point. This is true for most entrepreneurial firms which have limited resources.

The concave response function assumes that there are sufficient customers who have a clear and recognized need for the firm products and are willing to pay the asking price. This need is frequently the result of the firm achievement, usually an outcome of $\mathrm{R} \& \mathrm{D}$, in coming up with a product or a service that solves a clear and immediate problem. The concave response in each new market could also be the result of publicity and spill-over effects from early entered markets. According to the concave function the firm can get the best return on their marketing effort right from the start. With additional effort and time the firm is likely to face more skeptical buyers and increased effort by competitors which will lead to diminishing returns. Quick and early diversification is therefore the preferred strategy.

The second key factor is the complexity of the product, or service, from a marketing point of view (York 2018).

A complex product means that the potential customers have difficulty in buying, and, or using the product. There could be many aspects of complexity and it is a matter of degree. If the customer needs training to use the product, if the customer has to modify habits or systems, if the customer needs to go through an approval process to get the product, if the customer faces a cumbersome buying process, the product could be considered complex. Many expensive products, of a technical nature can be considered complex. In comparison, a self-service SaaS (software as a service) product of a low cost, where the customers understand how to download and how to use the product, can be considered simple. Many physical products, like a shirt, can also be considered simple. However, physical products are usually more complex than many digital products due to the purchasing process that requires shipping, storage and distribution. But some expensive and innovative digital products can also be complex and require an elaborate process of purchasing, approval and training. But it is important to note that an innovative complex product that solves critical issues could still be facing a high demand of an urgent nature. An example is the first CT head scanner by EMI in 1973, which met with an overwhelming response and enormous early success (Bartlett 1985). 
Table 1 shows a basic summary of the two critical factors discussed above for determining the preferred rate of market expansion.

Table 1. Critical factors for the rate of global market expansion

\begin{tabular}{lll}
\hline & Simple Product & Complex Product \\
\hline Concave Response Function & Fast Diversification & $\begin{array}{l}\text { Moderate to Fast Expansion based } \\
\text { on Distribution Availability and } \\
\text { Resources }\end{array}$ \\
\hline S-curve Response Function & $\begin{array}{l}\text { Incremental to Moderate Expansion } \\
\text { based on Feedback and Corrective } \\
\text { Action }\end{array}$ & \\
& & \\
\hline
\end{tabular}

As we can see in Table 1, there are two relatively clear cut cases for determining the desired rate of expansion:

Case 1. In the case of a simple product and a concave response function, fast diversification is recommended. The simple, usually digital, product makes it possible to expand fast from an operational point of view and the concave response makes it profitable to expand fast from a strategic and marketing point of view. This recommendation is dependent of course on the assumption that the firm has a reliable functioning product, there is minimal or no product adaptation required and there are no serious external limitations for market entry into many countries.

Case 2. The opposite situation can be viewed for the case of a complex product and a S-curve response function. A complex product may require education and training of customers, a long purchasing cycle, logistics of shipment, storage, and distribution for physical products and sometimes more bureaucratic regulations. In many technical products spare parts and maintenance may also be required. All these take time to setup properly for each entered market. If in addition, the expected, or actual, response function is an S-curve, it makes sense to expand gradually in a concentrated fashion, to make sure that a takeoff point is achieved in each entered market. The early effort will take time and resources to generate results.

Case 3, of a complex product and a concave response function require consideration of additional factors. The desired response from a marketing point of view is to expand rapidly in order to satisfy the demand and do it before competitors come in. A complex product may require a variety of activities in the process of marketing, these could include recruiting and developing a salesforce for each market, negotiating contracts (for expensive products) and organizing education and training. For physical products there are also possible external factors of logistics (shipping and storage), organizing distribution, service and administrative bureaucratic regulations. With a complex product other internal limitations, such as financial, manufacturing and managerial resources are likely to play a bigger role. The additional unique activities required for a complex product could moderate a desired fast expansion. A possible solution to some of the limitations is to use external marketing channels in all or in some markets and thereby expedite global market entry.

Case 4, of a simple product and an anticipated S-curve response require caution. While the logistics of the product makes it possible to expand rapidly, market demand requires cultivation which is likely to take time and resources. It is not advisable to expand too rapidly and gain a reputation of failure. A moderate expansion with investment in marketing education and attentive measuring of both behavioral and diagnostic feedback is recommended in this case.

\section{Response Function Estimation}

With an anticipated response function as a critical factor, an important question is how to assess it.

There are four basic approaches to assess the anticipated response function:

1. Survey of potential customers. The data could be interpreted by a model of new product diffusion. (Zif, 1967, Nielsen 2015)

2. Using a model of new product diffusion based on historical data with similar products. (Ofek, 2013)

3. Systematic experimentation. (Eastlack and Rao, 1986)

4. Using data from early feedback of product introduction in one or more markets. (Lodish, Morgan, Archambeau and Babin, 2016, for all approaches) 
A combination of these methods can be used. Surveys and historical data can be used prior to entry. Data from experimentation or from actual entry can be used when available to update estimates. Many external factors and situations can affect the estimated response function, but recognizing the shape of the response does not require precise accuracy of parameters. The response could also vary between markets and if the shape is very different, strategy adaptation will be required.

The process of estimating the relationship between marketing efforts and sales can be done in a direct way or in an indirect way. (Zif, 1967, Bowman and Catignon, 2009) See Figure 3.

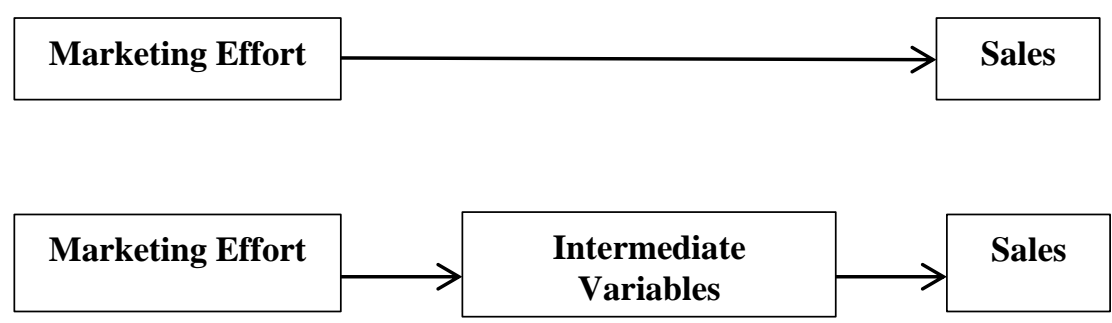

Figure 3. The relationship between marketing efforts and sales

The indirect way is based on using a set of intermediate variables between the marketing effort and sales. These intermediate variables usually include elements of the behavioral process which makes it possible to improve both forecast and diagnosis. An example for consumer products could include variables such as: distribution availability, initial consumer purchase, repeat purchase and rate of consumption. An early estimate of these behavioral variables in market surveys and tests could provide a reasonable estimate of the nature of the anticipated response. A strong initial and repeat purchase intention could indicate the possibility of a concave response function. A weak initial and response intentions is most likely an indication of an S-curve. Validation could come based on early sales by final consumer in one or more markets.

\section{Additional Factors Affecting the Rate of Market Expansion}

In this section we would like to summarize additional factors, beyond response function and product complexity, that could influence the chosen rate of market expansion. These factors can be grouped into three categories.

1. The ability of the firm to properly supply the goods or services.

2. External conditions other than consumers' demand

3. Managerial motivation, knowledge and goals.

1. The ability to properly supply too many different markets could be influenced by the following: production capacity and reliability, available financial and managerial resources, the need for product and communication adaptation from market to market, the need for managing a complex introduction program including preparation of service, training and maintenance. A limitation caused by any of these factors could slow a strategy of fast entry.

2 External conditions which could affect the rate of entry include: administrative and bureaucratic constrains in different markets, economic, political and environmental conditions (for example, the Corona virus epidemic), potential time for competitive response, industry that is typical of "winner takes all' and availability of reliable intermediaries. External constrains would slow the rate of expansion. A short competitive lag time and a "winner take all" industry would expedite fast entry. Availability of reliable intermediaries makes it possible to expand rapidly by relying on the resources and connections of various agents or distributers. The firm could also use a mixed strategy of concentrating its own marketing efforts in a few key markets and at the same time expand rapidly to other markets by relying on intermediaries.

3 Managerial goals and motivation influence all strategic decision making. Some entrepreneurial managers, with technical background, but limited marketing knowledge or international experience, may be hesitant to expand too rapidly and thus possibly lose control. A bold, global oriented, entrepreneurial leader can push for fast expansion.

\section{Conclusions}

The topic of fast internationalization by entrepreneurial firms has received attention from a variety of disciplines and points of view. Much of the research explains the phenomena with a variety of relevant factors. 
This paper concentrates on choosing the rate of global market expansion by entrepreneurial firms, rather than on explaining behavior. The choice is explored from a marketing point of view based on the assumption that the entrepreneurial firm has a reliable product, has the capacity to produce in sufficient quantities and has the necessary managerial and financial resources to enter new markets.

The driving force for the rate of expansion decision is customers' needs and willingness to buy. We have reviewed two extreme functions of customers' response: A concave function and an S-curve function. In general, fast expansion is preferred in the case of a concave function while an incremental expansion is usually preferred in the case of an anticipated S-curve response. But a second key consideration is product or service complexity. When customers have difficulty in buying or in using the innovative product, the product can be considered complex. High complexity is holding back fast market expansion, but it is less critical than customers' needs as expressed by the response function. There are many examples of innovative technological products that were expanded rapidly, in spite of their complexity.

Some points need to be emphasized:

1. The response function could frequently be between the two extremes, and the implied strategy should be moderated accordingly.

2. For a variety of reasons, the response function will not be the same in all markets, although clusters of markets are likely to be similar in their response. It is a common rational that global marketing strategy needs to be adjusted to the different market segments. Readiness for strategic change following feedback from entry into new markets is important (Zif 2019).

3. The use of a mixed strategy, where a firm can rely on intermediaries is some markets and use internal efforts in other priority markets, makes it possible to expand rapidly in spite of internal or external limitations.

4. Digital products are more likely to be less complex than physical products and the frequency of product improvements and modifications is much greater. This would mean a higher justification for a faster global market entry.

5. The paper outlines additional factors which may need to be considered in making the decision about the rate of global market expansion.

6. An entrepreneurial firm needs to balance between two risks: the risk of moving too fast and the risk of moving too slow. This paper offers some guidance in balancing these risks.

\section{References}

Ayal, I., \& Zif, J. (1979). Market expansion strategies in multinational marketing. Journal of Marketing, 43, 84-94. https://doi.org/10.1177/002224297904300209

Bartlett, C. A. (1985). EMI CT Scanner (B). Harvard Business Review.

Bowman, D., \& Catignon, H. (2009). Market response and marketing mix models: trends and research opportunities. Foundation and Trends in Marketing, 4(3), 129-207. https://doi.org/10.1561/1700000015

Cavusgil, S. T., \& Knight, G. (2015). The borm global firm: An entrepreneurial and capabilities perspective on early and rapid internationalization. Journal of International Business Studies, 46(1), 3-16. https://doi.org/10.1057/jibs.2014.62

Coviello, N. (2006). The network dynamics in the international new venture. Journal of International Business Studies, 37(5), 713-731. https://doi.org/10.1057/palgrave.jibs.8400219

Coviello, N. E., Kano, L., \& Liesch, P. (2017). Adapting the Uppsala model to a modern world: Macro-context and micro foundation. Journal of International Business Studies, 48(9), 1151-1164. https://doi.org/10.1057/s41267-017-0120-x

Eastlack, J. O. Jr., \& Rao, A. G. (1986). Modeling the Response to Advertising and Pricing Changes for "V8" Cocktail Vegetable Juice. Management Science, 5(3), 179-273. https://doi.org/10.1287/mksc.5.3.245

Fernhaber, S., McDougal, P., \& Oviatt, B. (2007). Exploring the role of industry structure in new venture internationalization. Entrepreneurship Theory and Practice, 31(4), 517-542. https://doi.org/10.1111/j.1540-6520.2007.00186.x

Hofer, C. W. (1975). Toward a continency theory of business strategy. Academy of Management Journal, 18, 804. https://doi.org/10.5465/255379 
Jehiel, Z. (1967). Marketing research as a system of information with application to the introduction of new products, Marketing for Tomorrow-Today. In M. S. Moyer, \& F. E. Vosburg (Eds.), The american marketing association, chicago (pp. 53-61).

Jehiel, Z. (2019). Entrepreneurial Marketing and Change Readiness. Journal of Management and Strategy, 10(1), 38-42. https://doi.org/10.5430/jms.v10n1p38

Joel, Y. (2018). SaaS Startup Strategies, Three SaaS Sales Models, Chaotic Flow.

Lodish, L. M., \& Morgan, H. L. (2016). Marketing that Works: How Entrepreneurial Marketing Can Add Sustainable Value to Any Sized Company. Paul Boger Publisher.

Mas Francisco, J., Nicolau, J. L., \& Felipe, R.-M. (2004). Foreign Diversification vs. Concentration Strategies and Firm Performance: Moderating Effects of the Market, Product and Firm Factors. International Marketing Review, 23(1), 54-82. https://doi.org/10.1108/02651330610646296

Mckinsey. (2014). You Tube, Grow Fast or Die Slow: Growth is Greater Than Margins.

Nielsen. (2015). Looking to Achieve New Product Success. Listen to Your Consumers.

Ofek, E. (2013). Forecasting the adoption of new products. Harvard Business Review.

Oviatt, B. M., \& McDougall, P. P. (2005). Defining international entrepreneurship and modeling the speed of internationalization. Entrepreneurship Theory and Practice, 29(5), 537-554. https://doi.org/10.1111/j.1540-6520.2005.00097.x

Philip, K. (1971). Marketing Decision Making-A Model building Approach (pp. 31-37). New York, Holt, Rinehart and Winston.

Seev, H., \& Lev, B. (1971). Sales stabilization through export diversification. The Review of Economics and Statis-tics, 53, 270-279. https://doi.org/10.2307/1937971 